\title{
Relationship between Macroinvertebrates and Physico-Chemical Parameters to Access Water Quality of the Affon River in Bénin
}

\author{
Fadéby Modeste Gouissi*, Olakonlé Samon, Koudjodé Simon Abahi, David Darius Adje, \\ Christelle Madina Tchaou, Zoulkanerou Orou Piami, Jeff Gildas Antoine Okoya, \\ Midogbo Pierre Gnohossou
}

Department of Management of Natural Resources (AGRN), Water and Soil Engineering, Laboratory of Ecology, Health and Animal Production (LESPA), Faculty of Agronomy (FA), University of Parakou (UP), Parakou, Bénin

Email: ^gouissi@yahoo.fr

How to cite this paper: Gouissi, F.M., Samon, O., Abahi, K.S., Adje, D.D., Tchaou, C.M., Orou Piami, Z., Okoya, J.G.A. and Gnohossou, M.P. (2019) Relationship between Macroinvertebrates and Physico-Chemical Parameters to Access Water Quality of the Affon River in Bénin. Advances in Entomology, 7, 92-104.

https://doi.org/10.4236/ae.2019.74008

Received: August 23, 2019

Accepted: September 17, 2019

Published: September 20, 2019

Copyright $\odot 2019$ by author(s) and Scientific Research Publishing Inc. This work is licensed under the Creative Commons Attribution International License (CC BY 4.0).

http://creativecommons.org/licenses/by/4.0/

\begin{abstract}
The Affon River is one of the important rivers of the Ouémé River whose benthic diversity remained unknown. The present study aims to make the relationship between macroinvertebrates and physico-chemical parameters to access water quality of the Affon River. The measurement of physico-chemical parameters (temperature, $\mathrm{pH}$, conductivity, transparency, depth and TDS, dissolved oxygen, ammonium, nitrite and phosphate) and the sampling of macroinvertebrates using a Surber net were carried out during floods in eight stations. A principal component analysis (PCA) and canonical correspondence analysis (CCA) were used. The indices of Shannon, Piélou, Simpson, Hilsenhoff, EPT and EPT/Chironomidae were used to assess the level of water pollution. The study identified 9755 macroinvertebrates divided into 4 classes, 14 orders and 49 families. Pollution-sensitive families (14 families) that are organic pollution indicators, as well as pollution-tolerant families (Chironomidae, Limnaeidae, Bithynidae, Physidae) were captured. Chironomidae were the most predominant and abundant family $(\mathrm{FO}=100 \%)$. The predominance of Chironomidae coupled with the rarity of the Ephemeroptera, Trichoptera and Plecoptera would reflect the poor quality of the Affon River waters. The principal components analysis yielded groups of associations: The first group of stations Taneka 2 and 3 characterized by high values of ammonium and phosphate; and low values of conductivity and TDS; the second group of Tanéka 1 and Kolokondé 1 stations with low values of $\mathrm{pH}$, transparency, ammonium and phosphates; and the third group of stations Kolokondé 2, Kpébouko1, Kpébouko 2 and Affon marked by high values of conductivity, TDS, transparency, depth and temperature. The canonical correspondence analysis revealed a strong positive correlation between Nemou-
\end{abstract}


ridae and ammonium as well as between Perlidae, Taeniopterygidae, Ephemeridae, Heptageniidae, Isonychiidae, Elmidae and phosphate. This study is a crucial step for any management and monitoring of this river.

\section{Keywords}

Macroinvertebrates, Diversity, Biotic Indices, Environmental Variables, Water Quality, Affon River

\section{Introduction}

Agricultural intensification is the major cause of degradation of aquatic ecosystems in rural areas [1]. The increase in production and yield requires the use of synthetic chemicals such as mineral fertilizers for soil and pesticide fertilization for weed control and phytosanitary treatment of plants. These agricultural activities on watersheds have serious ecological implications for rivers [2]. After their use, these pesticides and agricultural inputs are dispersed in different compartments of the environment. More than $99 \%$ of these pesticides are used in ecosystems to pollute water, land and air [3]. Pesticide damage is heavy for water resources, for aquatic populations in general. Because they degrade populations, cause poisoning, induce biocenotic disturbances and even sometimes lead to the extinction of biodiversity [3]. Among this biodiversity, the fauna that should be highlighted is the group of macroinvertebrates because they are excellent indicators of human impacts especially contamination [4]. These benthic macroinvertebrates are easy to sample, abundant and sedentary in all streams [5]. Unlike chemical analyzes, benthic macroinvertebrates can detect disturbances that occur even if they are no longer present at the time of sampling [6]. This makes them good witnesses to local conditions [7]. Hence these are used as bioindicators in many studies evaluating the biological quality of aquatic ecosystems. While the use of any biological community in conservation systems and/or water monitoring requires the characterization of its diversity and its structure [8]. Indeed, in Benin, some studies have been devoted to macroinvertebrates in rivers such as: Alibori [9] [10]; Oueme [11] [12]; Sô [13] and Sota [14]. These studies reinforce the state of knowledge on macroinvertebrates and know their importance. Despite these studies, our knowledge is still limited on the diversity and distribution of macroinvertebrates with respect to altitude. Therefore, the study aims to gain a better understanding of benthic macroinvertebrate distribution and biodiversity of Affon River in order to assess its ecological quality.

\section{Materials and Methods}

\subsection{Study Area and Sampling Stations}

The Affon River is located on the right bank and in the classified forest of Upper Ouémé. This river is one of the tributaries of the Ouémé River. It has a length of 
$152 \mathrm{~km}$ and a catchment area of $4320 \mathrm{~km}^{2}$. The river is located in the Sudano-Guinean zone and is under the influence of the tropical climate characterized by the succession in the year of a single rainy season from April to October and a single dry season from November to March, marked by the preponderance of the harmattan. On the Affon River, 08 stations were selected after prospecting. They were chosen based on the sustainability of the water, the altitude, accessibility in all seasons, the depth and speed of the water [11]. Table 1 shows the characteristics of these different stations.

\subsection{Measurement of Water Physico-Chemical Parameters}

At each station, the measurements of physical parameters (temperature, depth, transparency, TDS, conductivity, $\mathrm{pH}$, oxygen) were carried out in situ very early in the morning between 08:00 and 12:00, before the sampling of macroinvertebrates to avoid any disturbance of the environment. Water temperature, TDS and conductivity were determined using a portable conductivity meter (HANNA HI 99300). The $\mathrm{pH}$ was measured with a portable $\mathrm{pH}$ meter (HANNA HI 98107). A Secchi disk with a graduated rope is used to measure the transparency of the water and depth of the stations. Water samples were made at each station in $500 \mathrm{ml}$ plastic bottles decontaminated and stored in a cooler containing ice for transport to the laboratory for analysis of the dissolved substances. The dissolved elements concentration's determination of the water samples was carried out in the Laboratory of Hygiene, Sanitation, Ecotoxicology and Environmental Health (HECOTES) using a spectrophotometer DR 6000. The chemical parameters such as ammonium, nitrite and phosphate were respectively measured by the Nessler method [15], the iron sulphate method and the Vanadomolybdic method with persulfate digestion.

Table 1. Location, geographic coordinates and characteristics of sampling stations.

\begin{tabular}{|c|c|c|c|c|}
\hline Stations & Codes & $\begin{array}{l}\text { Geographic } \\
\text { coordinates }\end{array}$ & Altitude & Pollution sources \\
\hline Tanéka-Koko1 & Tan1 & $\begin{array}{l}\text { N: } 09^{\circ} 51^{\prime} 21^{\prime \prime} \\
\mathrm{E}: 01^{\circ} 32^{\prime} 34^{\prime \prime}\end{array}$ & $484 \mathrm{~m}$ & Artisanal extraction of gold \\
\hline Tanéka-Koko2 & Tan2 & $\begin{array}{l}\text { N: } 09^{\circ} 53^{\prime} 89^{\prime \prime} \\
\text { E: } 01^{\circ} 47^{\prime} 48^{\prime \prime}\end{array}$ & $429 \mathrm{~m}$ & $\begin{array}{l}\text { Laundry, dishes, artisanal extraction } \\
\text { of gold }\end{array}$ \\
\hline Tanéka-Koko3 & Tan3 & $\begin{array}{l}\text { N: } 09^{\circ} 52^{\prime} 40^{\prime \prime} \\
\mathrm{E}: 01^{\circ} 30^{\prime} 80^{\prime \prime}\end{array}$ & $415 \mathrm{~m}$ & $\begin{array}{l}\text { Laundry, dishes, artisanal extraction } \\
\text { of gold }\end{array}$ \\
\hline Kolokondé1 & Kol1 & $\begin{array}{l}\text { N: } 09^{\circ} 53^{\prime} 94^{\prime \prime} \\
\text { E: } 01^{\circ} 47^{\prime} 44^{\prime \prime}\end{array}$ & $410 \mathrm{~m}$ & $\begin{array}{l}\text { Agricultural waste, washing of } \\
\text { motorcycles and Laundry }\end{array}$ \\
\hline Kolokondé2 & Kol2 & $\begin{array}{l}\text { N: } 09^{\circ} 57^{\prime} 17^{\prime \prime} \\
\text { E: } 01^{\circ} 51^{\prime} 43^{\prime \prime}\end{array}$ & $369 \mathrm{~m}$ & $\begin{array}{l}\text { Household waste, agricultural waste, } \\
\text { washing of motorcycles and Laundry }\end{array}$ \\
\hline Kpeboucol & Kpe1 & $\begin{array}{l}\text { N: } 09^{\circ} 57^{\prime} 15^{\prime \prime} \\
\text { E: } 01^{\circ} 51^{\prime} 43^{\prime \prime}\end{array}$ & $365 \mathrm{~m}$ & $\begin{array}{l}\text { Agricultural, household and } \\
\text { livestock wastes }\end{array}$ \\
\hline Kpebouco2 & Kpe2 & $\begin{array}{l}\text { N: } 09^{\circ} 56^{\prime} 58^{\prime \prime} \\
\text { E: } 01^{\circ} 50^{\prime} 54^{\prime \prime}\end{array}$ & $363 \mathrm{~m}$ & $\begin{array}{l}\text { Laundry, household and livestock } \\
\text { waste }\end{array}$ \\
\hline Affon & Aff & $\begin{array}{l}\text { N: } 09^{\circ} 57^{\prime} 46^{\prime \prime} \\
\text { E: } 01^{\circ} 51^{\prime} 78^{\prime \prime}\end{array}$ & $348 \mathrm{~m}$ & $\begin{array}{l}\text { Watering cattle, washing of } \\
\text { motorcycles and laundry }\end{array}$ \\
\hline
\end{tabular}




\subsection{Sampling of Macroinvertebrates}

The benthic macroinvertebrates were sampled at the 08 stations. They were taken by using a Surber sampler with a $500-\mu \mathrm{m}$ mesh. This material was placed on the bottom of the river, the opening of the net facing the watercourse and the substrate is scraped a few centimeters with the hand. Twelve samples with a unit area of $1 / 20 \mathrm{~m}^{2}$ were done per station: (08) eight on the dominant habitats and (04) on the marginal habitats as recommended by the standard IBGN and already used in the North of Benin by Abahi et al. (2018) [11]. The organisms collected in surber sampler were spilled in labeled jars and fixed to $10 \%$ formalin and then sent to the laboratory.

\subsection{Macroinvertebrates Identification}

In the laboratory, the captured macroinvertebrates were rinsed in order to rid them of the formalin and then they were sorted station by station under a binocular dissecting microscope. After the sorting, we grouped them according to their classes up to their families apart from oligochaetes, nemathelminths, hydracarians, hydrozoans, sponges, bryozoans and nemerteans that are kept aside such as Abahi et al. (2018) [11] has done. The following articles: "Benthic macroinvertebrates of the streams of 'la Nouvelle-Calédonie" by Mary (2017) [16], "Identification guide of the main benthic macroinvertebrates of freshwater from Quebec" written by Moisan (2010) [17], "Freshwater invertebrates: Systematics, biology, ecology" by Tachet et al. (2000) [18] and "Aquatic entomology" by McCafferty (1981) were the key highlighted supports in making the taxonomic determination after which macroinvertebrates were enumerated and then stored in pillboxes containing $70 \%$ alcohol.

\subsection{Data Interpretation}

The identified fauna data allowed us to calculate the following metrics and indices:

Taxonomic richness $(S)=$ number of taxa present in each station

Abundance $(N)=$ number of individuals from a taxonomic group in each station

Relative abundance $(N r)=$ ratio as a percentage of the number of taxon individuals in a station to the total number of individuals of all species of all stations.

Frequency of family observation $(\mathrm{FO})=\left(F_{i} \times 100\right) / F_{t}$ In such, $F_{i}=$ number of stations containing the family and $F_{t}=$ total number of stations studied. Three families were thus distinguished as Abahi et al. (2018) [11] has previously demonstrated. We have "very frequent families" ( $F \geq 50 \%)$, "frequent families" (25\% $\leq F \leq 50 \%)$ and "rare families" ( $F \geq 25 \%)$.

Shannon diversity index $(H)=-£ p_{i} \cdot \log _{2} p_{i}$, with $p_{i}$ meaning the relative abundance of the $i$ species in the sample. The Shannon index is expressed in bits. It was determined by station. Shannon index values obtained were used to assess water quality. The Shannon index is subdivided into three classes of water quality: $2 \leq H$ for clean water; $1<H<2$ for moderately polluted water and $H \leq 1$ for 
polluted water.

Piélou index $(E)=H / \log 2 S$ with $S$ standing for the total number of individuals.

Simpson index $(D)=1-£_{i=1}^{S}\left(p_{i}\right)^{2}$ with $S$ standing for the total number of individuals and $\mathrm{pi}=$ meaning the relative abundance.

Family biotic index (Hilsenhoff index): To determine the water quality of the different stations, the family biotic index developed by Hilsenhoff was used. It has been calculated as follows:

$$
F B I=\frac{\sum_{i}^{F} n_{i} t_{i}}{N}
$$

in which $F$ is the family number, $n_{i}$ is the number of individuals, $t_{i}$ is the tolerance value of the family $i$ and $N$ is the total number of individuals. The tolerance values of the macroinvertebrate families come from Hilsenhoff (Table 2).

\subsection{Statistics Analysis of Data}

The obtained data was processed using Excel 2010 software and R3.4.4 software [19]. The taxonomic richness, the taxonomic abundance, the average values of the physico-chemical parameters were calculated per each station. Parametric and non-parametric tests (test $t$ student and test of Kruskal-Wallis) were used to evaluate the variability of the taxonomic richness of the abundances and diversity indices at the 5\% threshold with the R3.4.2 software [19]. Moreover, the factorial correspondence analysis (FCA) was used for grouping the stations according to the similarity association of macroinvertebrate families. In addition, a canonical correspondence analysis (CCA) was performed using PAST statistical package [20].

\section{Results}

\subsection{Relationship between Macroinvertebrates and Physico-Chemical Parameters}

A canonical correspondence analysis (CCA) was performed to correlate physico-chemical parameters and macroinvertebrate densities (Figure 1). The contained information in the variables is controlled at $63.48 \%$ by the system of axis 1 and 2. Perlidae, Taeniopterygidae, Ephemeridae, Heptageniidae, isonychiidae, Elmidae, phosphate, depth, conductivity and TDS are strongly and positively associated with axis 1 whereas Pyralidae, Leptophlebiidae, Hydrophilidae, Tabanidae, Viviparidae, hydrophiloidae, Nemouridae, Dytiscidae and ammonium are negatively associated with this axis. In addition, Nemouridae, Dytiscidae, ammonium and phosphate are positively associated with axis 2 whereas Baetidae, Physidae, Veliidae, Ceratopogonidae, Gyrinidae, conductivity and TDS are negatively related to axis 2 . On the other hand, there is a strong positive correlation $(r=0.78)$ between Nemouridae and ammonium whereas between Perlidae, Taeniopterygidae, Ephemeridae, Heptageniidae, Isonychiidae, Elmidae and phosphate there is strong positive correlation (0.60). 
Table 2. Score pattern of Hilsenhoff index.

\begin{tabular}{ccc}
\hline Value of FBI & Water quality & Degree of organic pollution \\
\hline 0.00 à 3.75 & Excellent & Without organic pollution \\
3.76 à 4.25 & Very good & Slight organic pollution \\
4.26 à 5.00 & Good & Probable organic pollution \\
5.01 à 5.75 & Average & Substantially organic pollution \\
5.76 à 6.50 & Rather bad & Substantial organic pollution \\
6.51 à 7.25 & Bad & Very substantial organic pollution \\
7.26 à 10.00 & Very bad & Serious organic pollution \\
\hline
\end{tabular}

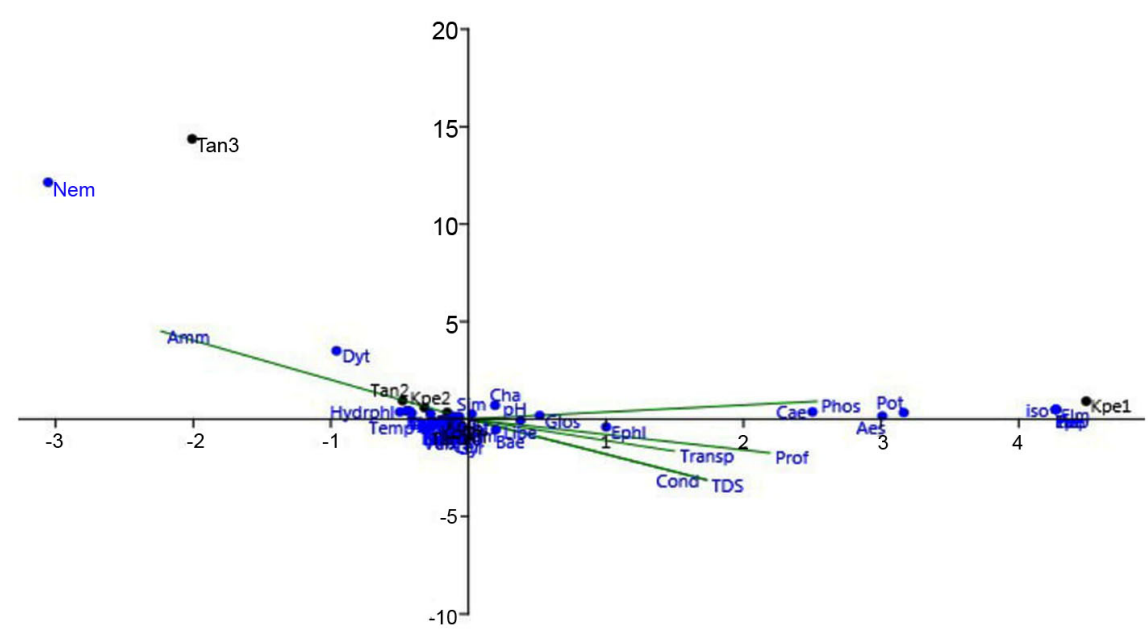

Figure 1. Canonical correspondence analysis of macroinvertebrates and physiochemical variables.

\subsection{Ecological Quality of the Affon River Waters}

\section{Spatial variation of the Shannon biodiversity index $(H)$}

Table 3 presents the values of the Shannon index and the water quality of the stations studied. Thus, the values of the Shannon index vary between 0.55 bit (Kolokondé 2 and Kpébouco 2) and 1.74 bits (Kpébouco 1). These results show that the water quality of the Affon River varied between polluted and moderately polluted (Table 3). In addition, Shannon index values showed significant differences between stations $(\mathrm{p}=0.001)$.

\section{Spatial variation of Piélou and Simpson's equitability indices}

The spatial variations of Piélou and Simpson's equitability indices are presented in Table 4. The Piélou equitability index ranged from 0.18 (Kpekouco 2) to 0.63 (Tanéka 2). While, Simpson's index fluctuated between 0.20 (Kpekouco 2) and 0.73 (Kpekouco 1). Finally, these indices showed significant differences ( $p>0.05$ ) between the stations (Table 4).

\section{Spatial variation of the EPT and EPT/Chironomidae indices}

Table 5 presents the values of the EPT and EPT/C indices per station. It reveals that Kpébouco 1 station has the highest value of the EPT index (54.1\%) while the lowest value (1.2\%) is observed at Kpébouco station 2. These low values 
Table 3. Shannon index values and ecological status of the stations.

\begin{tabular}{ccc}
\hline Stations & Value of Shannon $\left(\mathrm{H}^{\prime}\right)$ & Water quality \\
\hline Tan1 & 1.48 & Moderately polluted \\
Tan2 & 1.31 & Moderately polluted \\
Tan3 & 1.07 & Moderately polluted \\
Kol1 & 0.96 & Polluted \\
Kol2 & 0.55 & Polluted \\
Kpe1 & 1.74 & Moderately polluted \\
Kpe2 & 0.55 & Polluted \\
Aff & 1.46 & Very polluted \\
\hline
\end{tabular}

Table 4. Piélou and Simpson equitability indices.

\begin{tabular}{cccccccccc}
\hline Stations & Tan1 & Tan2 & Tan3 & Kol1 & Kol2 & Kpe1 & Kpe2 & Aff & $p$ \\
\hline Index of Pielou & 0.43 & 0.63 & 0.59 & 0.33 & 0.19 & 0.58 & 0.18 & 0.49 & 0.01 \\
Index of Simpson & 0.59 & 0.62 & 0.55 & 0.4 & 0.22 & 0.73 & 0.2 & 0.62 & 0.001 \\
\hline
\end{tabular}

Table 5. EPT and EPT/Chironomidae indices.

\begin{tabular}{ccccccccc}
\hline & \multicolumn{7}{c}{ Stations } \\
\hline Descriptors & Tan1 & Tan2 & Tan3 & Kol1 & Kol2 & Kpe1 & Kpe2 & Aff \\
\hline Taxonomic richness & 30 & 8 & 6 & 19 & 19 & 20 & 20 & 20 \\
EPT Richness & 8 & 1 & 2 & 4 & 4 & 10 & 3 & 3 \\
Total abundance & 2652 & 98 & 43 & 756 & 2940 & 468 & 1459 & 1339 \\
EPT abundance & 447 & 23 & 2 & 13 & 228 & 253 & 17 & 320 \\
Chironomidae abundance & 1645 & 55 & 12 & 577 & 2594 & 169 & 1306 & 780 \\
\% EPT & 16.9 & 23.5 & 4.7 & 1.7 & 7.8 & 54.1 & 1.2 & 23.9 \\
\% Chironomidae & 62.0 & 56.1 & 27.9 & 76.3 & 88.2 & 36.1 & 89.5 & 58.3 \\
EPT/Chironomidae & 0.3 & 0.4 & 0.2 & 0.0 & 0.1 & 1.5 & 0.0 & 0.4 \\
\hline
\end{tabular}

of the EPT index reflect the deterioration of the water quality of the Affon River. Regarding the percentage of Chironomidae, it is higher than $55 \%$ on all stations except Tanéka 3 and Kpébouco 1 stations. In addition, the values of the EPT/C index of the different stations are generally low and close to zero. These results indicate that the waters of the different stations are of poor ecological quality and reveal the environmental stress suffered by the Affon River.

\section{Family Biotic Index (Hilsenhoff Index)}

Figure 2 shows the spatial evolution of the Hilsenhoff index. Indeed, the maximum value of the Hilsenhoff index is observed at Kpébouco 2 station (7.72) while the minimum value is observed at Kpébouco 1 station (5.65). Thus, the water of the studied stations varies from average quality (rather substantial organic pollution) to very bad quality (serious organic pollution). The family biotic index 


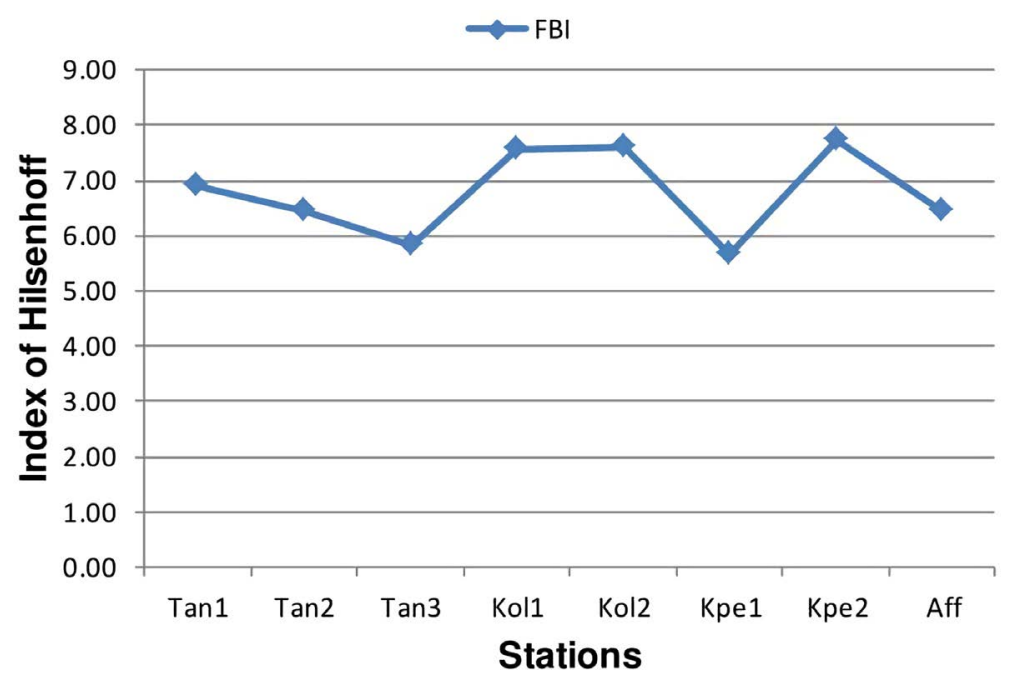

Figure 2. Hilsenhoff index variation.

(FBI) calculated for the Affon River is 7.14. This high value of the family biotic index indicates that the water of this river is of poor quality and that it presents a very substantial organic pollution.

\section{Discussion}

\subsection{Ecological Quality of Affon River Waters}

The calculated Shannon-Weaver index is less than 2 indicating that the waters of the stations have qualities varying between moderately polluted, polluted and very polluted. These results also reflect a lower biological diversity in the studied stations. The values of the Shannon diversity index recorded are lower than the values obtained by Foto et al. (2013) [21] in the Nga streams in Cameroon and by Koudenoukpo et al. (2017) [13] in the Sô River in southern Benin. But the low obtained values are consistent with the results of the river reported by Ibezute et al. (2016) [22] on the Ikpoba River in Nigeria. The maximum obtained values of Piélou's equitability index and Simpson's index are respectively 0.63 and 0.73 . These results show that macroinvertebrates are more or less well distributed at some stations of the Affon River. The low values of these indices at some stations show that they have minimal diversity and that the distribution of macroinvertebrates is less balanced, poorly organized and dominated by a single species. Overall, the waters of the Affon River have deteriorated. Similar findings have already been reported in several studies [10]. Indeed, the low percentage of pollution-sensitive families coupled with the percentage of Chironomidae indicates globally that the Affon River would have been deteriorated [5]. The low EPT/Chironomidae density values obtained are a perfect illustration of the environmental stress suffered by the Affon River, which would translate the bad quality of this river. These results are comparable to those observed by Foto et al. (2011) [23] in an anthropised watercourse in Cameroon and by Abahi (2018) [24] at the upper part of the Ouémé River. In addition, the strong obtained val- 
ues of the family biotic index (FBI) confirm once again and indicate that the water of the Affon River is of very poor quality and subjected to a very substantial organic pollution. These high values of the Hilsenhoff index indicate a degraded environment and are due to the preponderance of pollution-sensitive families such as Chironomidae [25]. These observations corroborate those made by Nuamah et al. (2018) [26] at Nima stream in Ghana. The observed water degradation can be attributed to discharges into the stream of agricultural and domestic effluents that contain nutrients [26] [27].

\subsection{Composition and Distribution of Macroinvertebrates}

The study has identified in the Affon River 9755 macroinvertebrates divided into 49 families. The observed taxonomic abundance is very low compared with the one reported by Agblonon Houelome et al. (2017) [9] at the Alibori River (39,718 individuals). On the other hand, it is higher than that of the upper Ouémé River, where there were 3657 individuals of macroinvertebrates [11]. As for the taxonomic richness, it is identical to the one reported at the Niger River [28] and at the Agnéby River in Côte d'Ivoire [29], while it is much higher than the one obtained by Abahi et al. (2018) [11] at the upper part of the Ouémé River. The differences observed with the study by Abahi et al. (2018) [11] in the same area are due to the Surber net and the sampling period. In fact, during this study, we used a 500 micrometer Surber net during floods, while Abahi et al. (2018) [11] used a 100 micrometer Surber net in low water. The diversity of the macroinvertebrate community harvested at the Affon River is marked by the importance of the Diptera (76.90\%) dominated by the Chironomidae family which represent $73.17 \%$ of the total abundance. In Benin, the study conducted by Abahi et al. (2018) [11] at the upper Ouémé River, also revealed the predominance of Insects (85.23\%), Diptera (81.65\%) and Chironomidae (67.35\%). Similarly, in Burkina Faso [30] and Kabré et al. (2000) [31] reported the dominance of Chironomidae in their studies. In addition, the study revealed the low diversity of pollution-sensitive orders (Ephemeroptera, Trichoptera and Plecoptera) both in terms of richness (14 families) and in terms of numbers (1303 individuals), which would probably reflect a poor water quality in the study area. These results, characteristics of the watercourses located in anthropized zones, corroborate well with the results obtained by (Abahi et al., 2018) [11] at the upper part of the Ouémé river, by Imorou Toko et al. (2012) [10] in the Benin cotton basin and by Orou Piami (2018) [14] at the Sota River. Most encountered families are represented by only a few individuals. But Chironomidae (Diptera) are frequently $(\mathrm{FO}=100 \%)$, and abundantly represented at all stations. Thus, the diversity of the Diptera order observed and especially of the Chironomidae family reveals an accumulation of nutrients in the ecosystem; consequences of intense human activities [26] [32]. Anthropogenic activities near ecosystems disturb benthic communities and contribute to reduced species richness and even species distribution [30] [33]. In addition, the correlations established between families and the physicochemical parameters show a strong positive correlation between Nemouridae and ammo- 
nium on the one hand and between Perlidae, Taeniopterygidae, Ephemeridae, Heptageniidae, isonychiidae, Elmidae and phosphate where there was a strong positive correlation. These correlations show the invulnerability of these families, which are mostly pollution-sensitive families, at the doses of phosphate and ammonium measured in this study.

\section{Conclusion}

The present study inventoried 9755 macroinvertebrate individuals belonging to four classes, fourteen orders and forty-nine families. Insects were the most dominant with $97.40 \%$ of the total richness. Taxonomic richness and abundance tend to follow an altitudinal gradient. The analysis of the indices reveals an undiversified population and the environmental stress that this river undergoes. The strong positive correlations observed between Nemouridae and ammonium on the one hand and between Perlidae, Taeniopterygidae, Ephemeridae, Heptageniidae, isonychiidae, Elmidae and phosphate show the invulnerability of these families, which are mostly pollution-sensitive families, at the doses of phosphate and ammonium measured in this study. Nevertheless, certain protection and recovery measures must be taken to preserve and improve the ecological status of the Affon River waters. It involves the implementation of a sustainable river management plan, the promotion of organic farming, the awareness of the population on the importance of water and its quality. In addition, a long-term investigation based on biomonitoring and a sustainable management program are recommended to conserve the biodiversity of this river.

\section{Acknowledgements}

We thank the people of our sampling places for their participation in the study. Special thanks go to the team of the Laboratory of Hygiene, Sanitary, Ecotoxicology and Environmental health (HECOTES) and the team of the Laboratory of Ecology, Health and Animal Production (LESPA).

\section{Conflicts of Interest}

The authors declare that they have no conflict of interest.

\section{References}

[1] Leigh, C., Burford, M.A., Robert, D.T. and Udy, J.W. (2010) Predicting the Vulnerability of Reservoirs to Poor Water Quality and Cyanobacterial Blooms. Water Research, 44, 4487-4496. https://doi.org/10.1016/j.watres.2010.06.016

[2] Hepp, L.U., Milesi, S.V., Biasi, C. and Restello, R.M. (2010) Effects of Agricultural and Urban Impacts on Macroinvertebrates Assemblages in Streams (Rio Grande do Sul, Brazil) Zool. Curitiba, 27, 106-113. https://doi.org/10.1590/S1984-46702010000100016

[3] Agbohessi, T.P., Toko, I.I. and Kestemont, P. (2012) État des lieux de la contamination des écosystèmes aquatiques par les pesticides organochlorés dans le Bassin cotonnier béninois. Cahiers Agricultures, 21, 46-56.

https://doi.org/10.1684/agr.2012.0535 
[4] Benetti, C.J., Pérez-Bilbao, A. and Garrido, J. (2012) Macroinvertebrates as Indicators of Water Quality in Running Waters: 10 Years of Research in Rivers with Different Degrees of Anthropogenic Impacts. In: Ecological Water Quality-Water Treatment and Reuse, InTech, London.

[5] Moisan, J., Pelletier, L., Gagnon, E., Piedboeuf, N. and La Violette, N. (2013) Guide de surveillance biologique basée sur les macroinvertébrés benthiques d'eau douce du Québec, 2e ed. Direction du suivi de l'état de l'environnement.

[6] Chessman, B.C. (1995) Rapid Assessment of Rivers Using Macroinvertebrates: A Procedure Based on Habitat-Specific Sampling, Family Level Identification and Biotic Index. Australian Journal of Ecology, 20, 122-129.

https://doi.org/10.1111/j.1442-9993.1995.tb00526.x

[7] Camargo, J.A., Alonso, A. and De La Puente, M. (2004) Multimetric Assessment of Nutrient Enrichment in Impounded Rivers Based on Benthic Macroinvertebrates. Environmental Monitoring and Assessment, 96, 233-249. https://doi.org/10.1023/B:EMAS.0000031730.78630.75

[8] Allan, J.D. and Johnson, L.B. (1997) Catchment-Scale Analysis of Aquatic Ecosystems. Freshwater Biology, 37, 107-111. https://doi.org/10.1046/j.1365-2427.1997.00155.x

[9] AgblononHouelome, T.M.A., Adandedjan, D., Chikou, A., ImorouToko, I., Koudenoukpo, C.Z., Youssao, I. and Laleye, P. (2017) Inventaire et caractéristiques faunistiques des macroinvertébrés de la rivière Alibori dans le bassin cotonnier du Bénin. International Journal of Innovation and Applied Studies, 21, 433-448.

[10] Imorou Toko, I., Attakpa, E.Y., Gnohossou, P. and Aboudou, E.F. (2012) Biodiversité et structure des macroinvertébrés benthiques du bassin cotonnier béninois. Annales des Sciences Agronomiques, 16, 165-182.

[11] Abahi, K.S., Gnohossou, P., Akodogbo, H.H., Orou Piami, Z., Adje, D., Tchaou, C. and Okoya, J. (2018) Structure et diversité des macroinvertébrés benthiques de la partie supérieure du fleuve Ouémé au Bénin. Afrique Science: Revue internationale des sciences et technologie, 14, 259-270.

[12] Zinsou, H.L., Gnohossou, P., Adandedjan, D. and Laleye, P. (2016) Profil de distribution des macroinvertébrés benthiques du delta de l'Ouémé à partir du Self Organizing Map (SOM). Afrique Science, 12, 224-236.

[13] Koudenoukpo, Z.C., Chikou, A., Imorou Toko, I., Togouet, S.H.Z., Tchakonté, S., Hazoume, R. and Piscart, C. (2017) Diversity of Aquatic Macroinvertebrates in Relationship with the Environmental Factors of a Lotic Ecosystem in Tropical Region: The Sô River in South-East of Benin (West Africa). Journal of Entomology and Zoology Studies, 5, 1-10.

[14] Orou Piami, Z. (2018) Diversité et distribution spatiale des macroinvertébrés benthiques de la rivière Sota au Bénin. Mémoire pour l'obtention du Diplôme de Master Recherche de l'Ecole Doctorale des Sciences Agronomiques et de l'eau de l'Université de Parakou, Bénin, 43 p.

[15] APHA (1992) Standard Methods for the Examination of Water and Wastewater. 18th Edition, American Public Health Association (APHA), Washington DC.

[16] Mary, N. (2017) Les macroinvertébrés benthiques des cours d'eau de la Nouvelle-Calédonie. Guide d'identification. Version révisée 2017, DAVAR Nouvelle-Calédonie. ed, OEIL, CNRT.

[17] Moisan, J. (2010) Guide d'identification des principaux macroinvertébrés benthiques d'eau douce du Québec, 2010: Surveillance volontaire des cours d'eau peu profonds. Direction du suivi de l'état de l'environnement, ministère du Développe- 
ment durable, environnement et parcs Québec.

[18] Tachet, H., Richoux, P., Bournaud, M. and Usseglio-Polatera, P. (2000) Invertébrés d'eau douce: Systématique, biologie, écologie. CNRS Ed. 588 p.

[19] R Core Team (2018) R: A Language and Environment for Statistical Computing. R Foundation for Statistical Computing, Vienna, Austria.

[20] Hammer, Ø., Harper, D.A.T. and Ryan, P.D. (2001) Paleontological Statistics Software: Package for Education and Data Analysis. Palaeontologia Electronica, 4, 9-18.

[21] Foto, M.S., Tchakonté, S., Ajeagah, G.A., Zebaze, T.S.H., Bilong, B.C.F. and Njiné, T. (2013) Water Quality Assessment Using Benthic Macroinvertebrates in a Periurban Stream (Cameroon). International Journal of Biotechnology, 2, 91-104.

[22] Ibezute, A.C., Asibor, G.I. and Ibezute, S.U. (2016) Ecological Assessment of Brewery Effluent Impact on the Macrobenthic Invertebrates of Ikpoba River, Edo State, Nigeria. International Journal of Ecosystem, 6, 47-54.

[23] Foto, M.S., Zebaze, T.S.H., Nyamsi, T.N.L., Ajeagah, G.A. and Njiné, T. (2011) Evolution Spatiale de la Diversité des Peuplements de Macroinvertébrés Benthiques dans un cours d'eau Anthropisé en Milieu Tropical (Cameroun). European Journal of Scientific Research, 55, 291-300.

[24] Abahi, S. (2018) Les macroinvertébrés de l'Ouémé supérieur: Abondance, diversité et variation spatiale. Mémoire pour l'obtention du Diplôme de Master Recherche de l'Ecole Doctorale des Sciences Agronomiques et de l'eau de l'Université de Parakou, Bénin, $77 \mathrm{p}$.

[25] Grandjean, F., Momon, J. and Bramard, M. (2003) Biological Water Quality Assessment of the White-Clawed Crayfish Habitat Based on Macroinvertebrate Communities: Usefulness for Its Conservation. Bulletin français de la pêche et de la pisciculture, 370, 115-125.

[26] Nuamah, L.A., Huang, J. and Dankwa, H.R. (2018) Biological Water Quality Assessment of Shallow Urban Streams Based on Abundance and Diversity of Benthic Macroinvertebrate Communities: The Case of Nima Creek in Ghana. Environment and Ecology Research, 6, 93-101. https://doi.org/10.13189/eer.2018.060201

[27] Nurhafizah-Azwa, S. and Ahmad, A.K. (2018) Biodiversity of Benthic Macroinvertebrates in Sungai Kisap, Langkawi, Kedah, Malaysia. Journal of Tropical Resources and Sustainable Science, 6, 36-40.

[28] Alhou, B., Issiaka, Y., Awaiss, A. and Micha, J.-C. (2014) Premier inventaire des macro-invertébrés du fleuve Niger à Niamey comme bioindicateurs de la pollution urbaine et industrielle. Hydroécologie Appliquée, 18, 139-163.

[29] Diomandé, D., Bony, Y.K. and Edia, E.O. (2009) Diversité des Macroinvertébrés Benthiques de la Rivière Agnéby (Côte d'Ivoire; Afrique de l'Ouest). European Journal of Scientific Research, 35, 368-377.

[30] Sanogo, S., Kabré, T.J.A. and Cecchi, P. (2014) Inventaire et distribution spatio-temporelle des macroinvertébrés bioindicateurs de trois plans d'eau du bassin de la Volta au Burkina Faso. International Journal of Biological and Chemical Sciences, 8, 1005-1029. https://doi.org/10.4314/ijbcs.v8i3.16

[31] Kabré, T.A., Illé, A. and Guenda, W. (2000) Inventaire et étude de la densité de distribution des insectes du benthos des deux lacs de barrage de Bagré. Revue Sciences et Techniques, Série Science Naturelle et Agronomie, 24, 121-132.

[32] Fu, L., Jiang, Y., Ding, J., Liu, Q., Peng, Q.-Z. and Kang, M.-Y. (2016) Impacts of Land Use and Environmental Factors on Macroinvertebrate Functional Feeding Groups in the Dongjiang River Basin, Southeast China. Journal of Freshwater Ecol- 
ogy, 31, 21-35. https://doi.org/10.1080/02705060.2015.1017847

[33] Pan, B., Wang, Z., Yu, G., Xu, M., Zhao, N. and Brierley, G. (2013) An Exploratory Analysis of Benthic Macroinvertebrates as Indicators of the Ecological Status of the Upper Yellow and Yangtze Rivers. Journal of Geographical Sciences, 23, 871-882. https://doi.org/10.1007/s11442-013-1050-6 